\title{
A review of social and economic performance of agroecology
}

\author{
Raffaele D'Annolfo (D) ${ }^{a}$, Barbara Gemmill-Herren (1D ${ }^{b}$, Benjamin Graeub (iD ${ }^{c}$ and Lucas A. Garibaldi (1) ${ }^{d}$ \\ ${ }^{a}$ Doctoral School on the Agro-Food System (Agrisystem), Università Cattolica del Sacro Cuore, Piacenza, Italy; ${ }^{b}$ World Agroforestry \\ Centre, Nairobi, Kenya; 'Mercator Fellow on International Affairs, Zurich, Switzerland; ${ }^{\mathrm{d}}$ Instituto de Investgaciones en Recursos \\ Naturales, Agroecología y Desarrollo Rural (IRNAD), Sede Andina, Universidad Nacional de Río Negro (UNRN) and Consejo \\ Nacional de Investigaciones Científicas y Técnicas (CONICET), Río Negro, Argentina
}

\begin{abstract}
Agroecology potentially offers a sustainable path to agricultural development as it integrates ecological principles and social and economic concerns into agri-food systems. While many descriptive studies have documented the experience of farming communities using agroecological approaches, evidence on social and economic indicators of agroecology is poorly documented in a quantitative sense. The present study aims to build a framework and provide a quantitative overview of the effects of adopting selected agroecological practices at the farm level. A literature review has been conducted in order to identify scientific work addressing the contribution of agroecology to a set of socio-economic indicators, which affect human, financial and social assets. Data extracted from 17 peer-reviewed papers were analysed using two techniques: vote counting and general linear mixedeffects models on effect sizes. We found preliminary evidence of agroecology's positive contribution to improving financial capital. However, data extracted does not provide meaningful information on other capital endowments (human and social). This is mainly due to the fact that there is a lack of data concerning the socio-economic impact of agroecology. In addition, qualitative methods (e.g. Qmethodology) should be integrated into further research in order to capture farmer perspectives.
\end{abstract}

\section{KEYWORDS}

Agroecology; agroecological practices; sustainable livelihoods framework; socioeconomic; sustainable agriculture; quantitative analysis

\section{Introduction}

Numerous recent reviews emphasize that future food and agricultural needs will have to be addressed by transitioning to regenerative systems of food production. These food systems should be based on an effective and enhanced use of ecosystem services that minimize negative impacts while improving or at least stabilizing yields and building natural and social capital (FAO, 2015; IAASTD, 2009; MEA, 2005; Tittonell et al., 2012).

At least $70 \%$ of the world's poor are concentrated in rural areas and rely on agriculture as a main source of income and employment (IFAD, 2011). Agroecological approaches offer an alternate path to conventional agricultural development as they integrate ecological principles as well as social and economic concerns into agricultural production and the wider food system (FAO, 2015). Their aim is to reduce dependency on external inputs and increase the productive capacity of biotic and abiotic system components.

Agroecological approaches require a knowledgeintensive process and optimal management of nature's ecological functions and biodiversity in order to improve, not only agricultural system performance and efficiency but also farmers' livelihoods. Altieri (2002) identifies several impacts on livelihood associated with use of agroecological improvements in addition to farm diversification (e.g. improved food security, reduced poverty and social exclusion and increased income).

Reviews of agroecology as a scientific discipline, as a set of agroecological practices and as a movement already exist (Uphoff, 2008; Wezel et al., 2014; Wezel 
\& Soldat, 2009). However, only few studies have attempted to identify the social and economic benefits associated with agroecological approaches at the farm level (Bacon, Getz, Kraus, Montenegro, \& Holland, 2012; Dumont, Vanloqueren, Stassart, \& Baret, 2016). This paper aims to assess from the available quantitative data the effects of agroecological practices on social and economic indicators, reflecting the sustainable livelihoods (SL) framework.

The present study requires a provisional definition of boundaries of agroecology, to assess what is an agroecological approach in the literature and what is not. Our aim is not to provide definitive answers but to raise questions, challenge assumptions on possible ways to assess social and economic impacts of agroecological practices and to suggest connections between agroecological practices and frameworks on SL that merit deeper investigation.

\section{Data and methods}

\subsection{Agroecological practices}

Agroecology is the integrative study of the ecology of the entire food system, encompassing ecological, economic and social dimensions (Francis et al., 2003). Agroecology can be characterized depending on the application of five basic principles: recycling, efficiency, diversity, regulation and synergies (Altieri, 2002; Gliessman, 2007; Tittonell, 2015), although socio-economic elements need incorporation and greater articulation.

Agroecological practices were identified using as a main source (Garbach et al. 2014, 2016). In order to test the feasibility of the approach proposed, a limited number of nine agroecological practices were considered in the current study, as defined below:

- Biological nitrogen fixation: the application of nutrients through use of species that can biologically fix nitrogen from the atmosphere and make it available to plants (Wagner, 2011).

- Direct seeding: seeds are sown directly into either permanent plant cover or residue from the previous crop that has been left on the ground, in addition to mulched dead or live cover (CorbierBarthaux, Loyer, \& Richard, 2007).

- Integrated aquaculture: systems based on the recycling of nutrients between farm components: farm wastes fertilize fish ponds, pond sediments fertilize crops and feed aquatic species (Soussana, Tichit, Lecomte, \& Dumont, 2015).

- Integrated nutrient management: maintenance of soil fertility and plant nutrient supply (e.g. manure) to minimize leaching of nutrients, including reducing nutrient losses through erosion control (Pretty, 2008).

- Minimal tillage: minimization of soil disturbance, with measures ranging from reducing the number of tillage passes, tillage depth or stopping tillage completely (Rusinamhodzi et al., 2011).

- Optimal plant spacing: using plant spacing to enhance resource-use efficiency; often there is less mortality and more vigorous growth of plants under wide spacing compared to close spacing (Choudhary \& Suri, 2013).

- Permanent soil cover: mulch (such as decaying leaves, bark or compost) is spread over the soil and around a crop to enrich and insulate the soil (FAO, 2014).

- Small-scale water-conserving irrigation: this includes a variety of practices (e.g. integrated ridge-furrow with plastic mulching; small-scale drip irrigation) which can promote rural food security, water use efficiency and adaptation to climate change (Tucker \& Yirgu, 2010).

- Use of compost or organic matter: compost and organic matter encompass a wide variety of living or dead plant and animal material, ranging from kitchen wastes and shredded leaves to well-rotted manure (Marshall Bradley, Ellis, \& Phillips, 2009).

We deliberately used a broad definition for the practices selected in line with general agroecological principles, which are not meant to be prescriptive. There is also a need to further clarify that genetically modified organisms (GMOs) do not represent a subject of the analysis. For this reason, studies concerning GMOs have not been taken into account even if they are integrated with the agroecological practices as defined above.

\subsection{Social and economic indicators}

We choose 10 social and economic indicators following the SL framework (Table 1). The SL framework represents one of the well-recognized tools to analyse poverty from a multidimensional perspective, which allows an improved understanding of social and economic relations at the farmer level. The SL framework has been employed for many years in rural areas 
(Baumann, 2002; Cleary, Baumann, Bruno, Flores, \& Warren, 2003; Garibaldi et al., 2016).

The SL framework has been adapted to our specific aim in order to show the socio-economic effects of adopting agroecological practices at the farm level (Table 1). However, because of our focus on a distinct subset of $\mathrm{SL}$, our analysis is largely restricted to household level capital endowment. ${ }^{1}$ It explicitly does not address other important endowments such as land tenure, infrastructure service and environmental characteristics. For this reason, natural and physical capital have not been considered in this analysis.

The 10 indicators selected to observe the effects of the agroecological practices with respect to the SL framework were:

- Yield: the measure of the amount of output per hectare produced by farmer.

- Farm profitability: the difference between gross farm income and expenses.

- Labour demand: the level of demand for labour at field level.

- Labour productivity: the ratio between a volume measure of output (yield) and a measure of input use, which can be the total number of hours worked or total employment (head count).

- Income stability: the return to farmer's labour over time.

- Percent farmer incorporating agroecological approaches: percentage of farmers trained in agroecology and choosing to incorporate agroecological farming systems.

- Access to the market: access for the products of agroecology in the commercial market.

- Number of registered groups: the number and quality of formal farming groups in a certain community.

- Influence on decision-making: the presence of formal procedures/rules allowing stakeholders to influence decision-making.

- Recognition/Assessment of transition costs: formal recognition of the costs for food producers to make the transition from conventional to agroecological production methods.

These indicators were selected to represent each of the three assets: human, financial and social capital. The indicators were then condensed into the following keywords: 'cost', 'empowerment', 'labour', 'market access', 'profitability' and 'revenue'. For several indicators, no data were available, and they
Table 1. SL framework including assets definition with related social and economic indicators.

\begin{tabular}{|c|c|}
\hline Assets & Social and economic indicators \\
\hline $\begin{array}{l}\text { Human capital: represents the } \\
\text { skills, knowledge, ability to work } \\
\text { and good health that together } \\
\text { enable farmers to pursue } \\
\text { different livelihood strategies } \\
\text { and achieve their livelihood } \\
\text { objectives }\end{array}$ & $\begin{array}{l}\checkmark \text { Labour productivity } \\
\checkmark \text { Labour demand } \\
\checkmark \text { Percentage of farmers } \\
\quad \text { incorporating } \\
\quad \text { agroecological approaches }^{\mathrm{a}}\end{array}$ \\
\hline $\begin{array}{l}\text { Financial capital: denotes the } \\
\text { financial resources that farmers } \\
\text { use to achieve their livelihood } \\
\text { objectives. There are two main } \\
\text { sources of financial capital: }\end{array}$ & $\begin{array}{l}\checkmark \text { Yield } \\
\checkmark \text { Farm profitability } \\
\checkmark \text { Income stability } \\
\checkmark \text { Recognition/Assessment of } \\
\quad \text { transition costs }^{\mathrm{a}}\end{array}$ \\
\hline $\begin{array}{l}\gg \text { available stocks } \\
\triangleright \text { regular inflows of money }\end{array}$ & \\
\hline $\begin{array}{l}\text { Social capital: in the context of } \\
\text { the sustainable livelihoods } \\
\text { framework, it refers to the social } \\
\text { resources upon which farmers } \\
\text { draw in pursuit of their livelihood } \\
\text { objectives. These are developed } \\
\text { through: }\end{array}$ & $\begin{array}{l}\checkmark \text { Access to the market } \\
\text { developed for the products } \\
\text { of agroecology }{ }^{\mathrm{a}} \\
\checkmark \text { Number and quality of } \\
\text { registered groups in a } \\
\text { certain community }{ }^{\mathrm{a}} \\
\checkmark \text { Presence of formal procedures/ } \\
\text { rules for allowing } \\
\text { stakeholders to influence } \\
\text { decision-making }^{\mathrm{a}}\end{array}$ \\
\hline
\end{tabular}

Note: Asset definitions are based on DFID (1999).

${ }^{\mathrm{a}}$ For this indicator, no quantitative data were found.

thus could not be further included in the analysis (Table 1).

\subsection{Literature search}

For the analysis of the scientific literature, peerreviewed papers and proceedings were searched within the Scopus database ${ }^{2}$ using a combination of agroecological practices and keywords listed in Sections $2.1^{3}$ and 2.2 (e.g. 'integrated nutrient management' AND 'profitability', 'minimal tillage' AND 'cost').

The top 10 results assessed by Scopus at the time of the analysis were taken into account. As of the end of June 2015, 99 out of 105 abstracts had been screened. ${ }^{4}$ Papers were reviewed against the following criteria: (i) the abstract mentioned one or more agroecological practices; (ii) the study provided comparisons with conventional practices and meaningful information on the selected socio-economic indicators. Our final database included 17 studies which met the criteria, providing 154 comparisons between conventional and agroecological practices (Table 2). 
Table 2. Main feature of the studies included in the meta-analysis.

\begin{tabular}{|c|c|c|c|c|c|c|c|}
\hline Reference & Practice(s) & Country & Crops and species & Yield & $\begin{array}{l}\text { Farm } \\
\text { profitability }\end{array}$ & $\begin{array}{l}\text { Labour } \\
\text { demand }\end{array}$ & $\begin{array}{l}\text { Labour } \\
\text { productivity }\end{array}$ \\
\hline $\begin{array}{l}\text { Cepeda and Gómez } \\
\text { (2010) }\end{array}$ & $\begin{array}{l}\text { Minimal tillage and permanent } \\
\text { soil cover }\end{array}$ & Mexico & Canola & $x$ & $x$ & & \\
\hline $\begin{array}{l}\text { Chaturvedi et al. } \\
(2012)\end{array}$ & $\begin{array}{l}\text { Use of compost or organic matter; } \\
\text { integrated nutrient } \\
\text { management }\end{array}$ & India & Soybean & $x$ & $x$ & & \\
\hline $\begin{array}{l}\text { Choudhary and Suri } \\
\text { (2013) }\end{array}$ & Optimal plant spacing & India & Rice & $x$ & $x$ & & \\
\hline $\begin{array}{l}\text { Demelash et al. } \\
\text { (2014) }\end{array}$ & $\begin{array}{l}\text { Integrated nutrient management; } \\
\text { use of compost or organic } \\
\text { matter }\end{array}$ & Ethiopia & Wheat & $x$ & $x$ & & \\
\hline Fukai and Ouk (2012) & Direct seeding & $\begin{array}{l}\text { Thailand, Laos } \\
\text { and } \\
\text { Cambodia }\end{array}$ & Rice & $x$ & & $x$ & \\
\hline Gautam et al. (2013) & Optimal plant spacing & India & Rice & $x$ & $x$ & & \\
\hline Gemtos et al. (1998) & $\begin{array}{l}\text { Minimal tillage and permanent } \\
\text { soil cover }\end{array}$ & Greece & Wheat & $x$ & $x$ & & \\
\hline Lestrelin et al. (2012) & $\begin{array}{l}\text { Minimal tillage and permanent } \\
\text { soil cover }\end{array}$ & Laos & Maize & $x$ & $x$ & $x$ & $x$ \\
\hline Liu et al. (2014) & Integrated aquaculture & China & $\begin{array}{l}\text { Shrimp, spotted } \\
\text { scat and water } \\
\text { spinach }\end{array}$ & $x$ & $x$ & & \\
\hline $\begin{array}{l}\text { Malabayabas et al. } \\
\text { (2014) }\end{array}$ & Direct seeding & Bangladesh & Rice & $x$ & $x$ & & \\
\hline $\begin{array}{l}\text { Maruthi Sankar et al. } \\
(2014)\end{array}$ & $\begin{array}{l}\text { Integrated nutrient management } \\
\text { and biological } \mathrm{N} \text { fixation; } \\
\text { Integrated nutrient } \\
\text { management }\end{array}$ & China & Cotton & $x$ & $x$ & & \\
\hline Qin et al. (2014) & $\begin{array}{l}\text { Permanent soil cover and small- } \\
\text { scale water-conserving } \\
\text { irrigation }\end{array}$ & China & Potato & $x$ & $x$ & & \\
\hline $\begin{array}{l}\text { Rathore, Singh, Meel, } \\
\text { and Nathawat } \\
\text { (2014) }\end{array}$ & Integrated nutrient management & India & $\begin{array}{l}\text { Moth bean, pearl } \\
\text { millet and cluster } \\
\text { bean }\end{array}$ & $x$ & $x$ & & \\
\hline Sandri et al. (2014) & $\begin{array}{l}\text { Small-scale water-conserving } \\
\text { irrigation }\end{array}$ & Brazil & Watermelon & $x$ & $\mathrm{x}$ & & \\
\hline $\begin{array}{l}\text { Sharma and Banik } \\
\text { (2014) }\end{array}$ & Use of compost or organic matter & India & Corn & $x$ & $x$ & & \\
\hline Smith et al. (2011) & Minimal tillage & USA & Corn & $x$ & $x$ & & \\
\hline Zhao et al. (2014) & $\begin{array}{l}\text { Permanent soil cover and small- } \\
\text { scale water-conserving } \\
\text { irrigation }\end{array}$ & China & Potato & $x$ & $x$ & & \\
\hline
\end{tabular}

Regarding the number of practices addressed in the selected studies, it is interesting to note that the integrated nutrient management and permanent soil cover represent $19.2 \%$ each (Table 3 ). These often-

Table 3. Agroecological practices addressed in the studies in percentage terms.

\begin{tabular}{lc}
\hline Practices & $\%$ \\
\hline Integrated nutrient management & 19.2 \\
Permanent soil cover & 19.2 \\
Minimal tillage & 15.4 \\
Small-scale water-conserving irrigation & 11.5 \\
Use of compost or organic matter & 11.5 \\
Direct seeding & 7.7 \\
Optimal plant spacing & 7.7 \\
Biological N fixation & 3.8 \\
Integrated aquaculture & 3.8 \\
\hline
\end{tabular}

mentioned practices are rarely applied in isolation; they are often associated with other practices (e.g. minimal tillage, use of compost or organic matter) (Table 2).

\subsection{Data analysis techniques}

The data extracted for the study were analysed using two techniques: vote counting and general linear mixed-effects models.

\subsubsection{Vote counting analysis}

This method has been widely used to investigate farmers' adoption of conservation agriculture and best management practices (Knowler \& Bradshaw, 
2007; Prokopy, Floress, Klotthor-Weinkauf, \& Baumgart-Getz, 2008). In order to identify the general trends between adopting agroecological practices and socio-economic indicators, the percentage change in the socio-economic indicators between agroecological and conventional practice was computed. The percentage change in $x(\% \Delta x)$ is calculated using Equation (1):

$$
\% \Delta x=100 *\left(\frac{\Delta x}{x_{c}}\right),
$$

where $\Delta x=x_{\mathrm{a}}-x_{\mathrm{c}}, \quad x_{\mathrm{a}}=$ value obtained adopting agroecology practices and $x_{c}=$ value obtained adopting for conventional practices

The magnitude effect has been set at $5 \%$ with the following results:

- Arrow $\uparrow$ (increased): if the percentage change is > $+5 \%$;

- Arrow $\leftrightarrow$ (neutral): if the percentage change is between $-5 \% \geq$ and $\leq+5 \%$;

- Arrow $\downarrow$ (decreased): if the percentage change is < $-5 \%$.

\subsubsection{General linear mixed-effects models on effect sizes}

We adopted general linear mixed-effects models for the indicators considered in the analysis. Ratios were estimated as the natural logarithm between the mean for agroecological practices and the mean for conventional practices (Borenstein, Hedges, Higgins, \& Rothstein, 2009). Other statistical analyses were not possible because only mean values were available from most studies (e.g. data on standard errors were missing). By including the study identity (ID) as a random variable, our models estimated intercepts (aj) for each study (j) to account for the hierarchical data structure (e.g. several studies provided more than one valid contrast) and differences among studies (random intercept models) (Gelman \& Hill, 2007; Qian, Cuffney, Alameddine, Mc Mahon, $\&$ Reckhow, 2010). If the overall intercept $(\beta 0)$ is greater than zero, it means that agroecological practices increase the value of the indicator, for example yield or profit, over all studies. We tested the Gaussian and homoscedasticity assumptions for the standardized residuals of the models, and these assumptions were valid in all cases. Analyses were performed with the Ime4 package (Bates, Mäechler, Bolker, \& Walker, 2015) of the R software (R Development Core Team, 2013).

\section{Results}

\subsection{Vote counting analysis results}

Generally, adopting agroecological practices increases the yield (61\%), profitability (66\%) and labour productivity (100\%) compared to conventional practices. The only indicator, which exhibits a decreasing value, is the labour demand (75\%) (Figure 1).

We also analysed the synergies and the trade-offs between profitability and yield with the following results: $59 \%$ positive, $18 \%$ negative, $7 \%$ neutral and $16 \%$ trade off (Figure 2 ).

Based on the data analysed, it has been possible to identify general trends of adopting agroecological

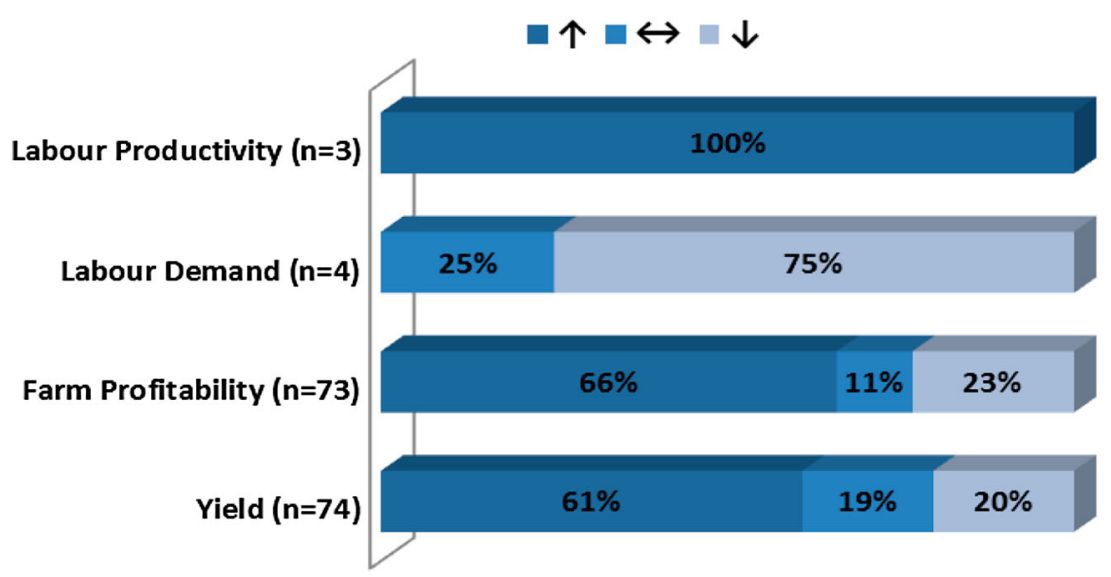

Figure 1. Effects of adopting agroecological practices on socio-economic indicators (relative frequencies). 


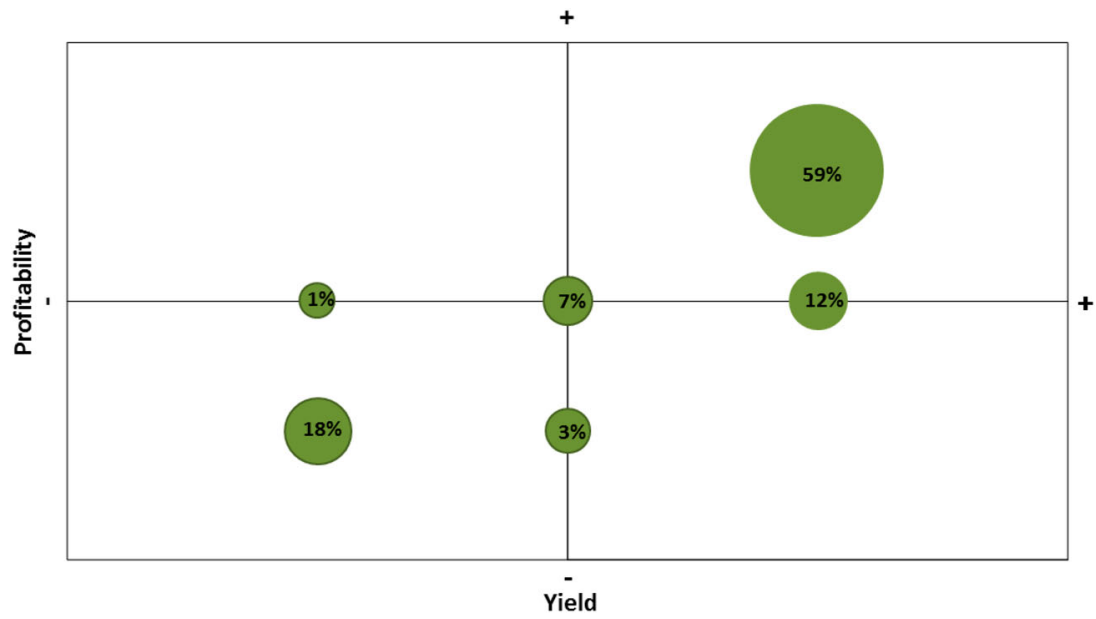

Figure 2. Effects of adopting agroecological practices simultaneously on both farm profitability and yield (relative frequencies). Notes: Bubble location indicates a specific combination of outcomes for profitability ( $y$-axis: enhanced, upper quadrants; diminished, lower quadrants) and yield ( $x$-axis: enhanced, right quadrants; diminished, left quadrants) relative to the comparisons between agroecological and conventional practices. Bubble size indicates the percentage of comparisons reporting each combination of profitability and yield.

practices on the SL framework. The absolute frequency of the indicators which fall under the same asset category have been summed up under that asset and the relative frequencies have been computed for the asset categories (Figure 3). The analysis shows that only financial and human capital have yielded sufficient data in terms of a comparison between agroecological versus conventional farming practices. Social capital has not been included here due to a lack of quantitative data encountered in our analysis. On one hand, financial capital increases using agroecological practices compared to conventional agriculture in 93 out of 147 comparisons (63\%). On the other hand, human capital shows no difference between agroecological and conventional practices (43\%). However, the low number of comparisons available for human capital should be highlighted $(n=7)$.

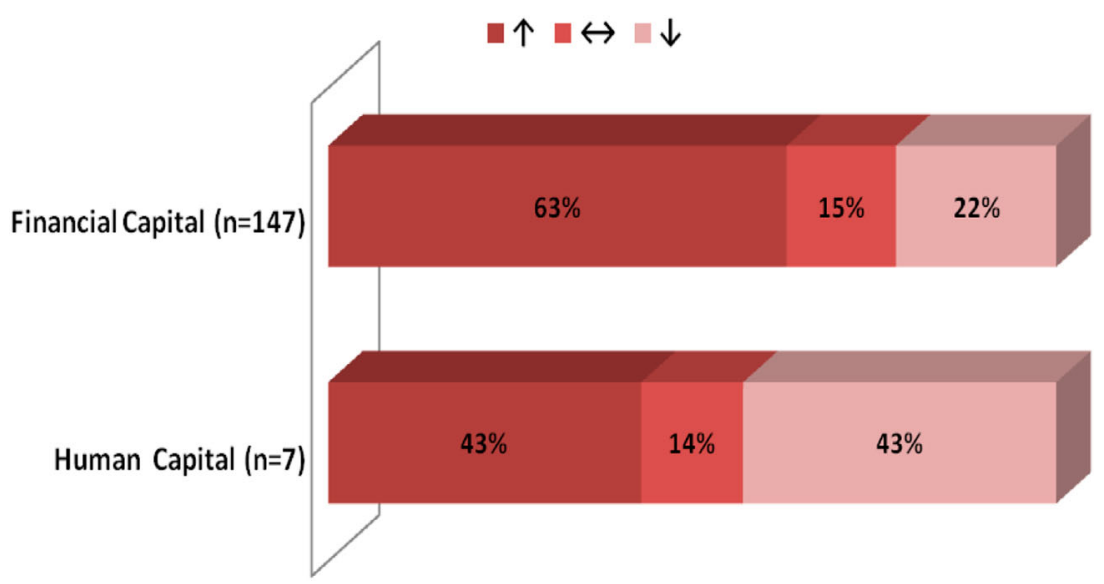

Figure 3. Effects of adopting agroecological practices on financial and human capitals (relative frequencies). 


\subsection{General linear mixed-effects models' results}

We estimated two general linear mixed-effects models, one for yield ratio and another for farm profitability ratio as response variables. Due to the small number of observations available for labour demand and labour productivity, these two indicators have not been included in the statistical analyses. Mixedeffects models showed that agroecological practices increased crop yield over conventional practices as the log response ratio (0.15) was greater than zero (95\% confidence interval between 0.053 and 0.248 ). Meta-analysis of 17 papers found that, on average, yields were $16 \%$ greater for agroecological practices. However, we did not find differences in farm profitability between agroecological and conventional practices, as the log response ratio did not differ from zero (95\% confidence interval between -0.255 and 1.077 ).

\section{Discussion}

\subsection{Limitations of the study}

The main limitations of the study are addressed in the following sections.

\subsubsection{Lack of available data}

Data have not been found for the following indicators: (i) percentage of farmers incorporating agroecological approaches; (ii) income stability; (iii) recognition/ assessment of transition costs; (iv) access to the market developed for the products of agroecology; (v) number and quality of registered groups; (vi) presence of formal procedures/rules for allowing stakeholders to influence decision-making. The focus of the selected papers is on the amount of output produced by farmers with respect to crop harvest levels or profitability, which is relevant to this analysis but tends to emphasize economic trends rather than social aspects. Moreover, the indicators listed above are not observable in the short-term and require long-term research, which implies another type of investment in terms of research funding.

\subsubsection{Sample size}

The number of observations found for labour productivity and labour demand was too small for further analysis. It did not allow the identification of significant relationships in the data, and for this reason the results cannot be generalized. A possible explanation is that only few scientific papers have attempted to assess not only the agronomical impacts of agroecology but also the impacts of the adoption of agroecological practices on socio-economic variables such as farm income, labour demand and employment generation. As an example, a Scopus search on agroecology indicated that since 1995, the combinations of 'agroecology' AND 'labour', 'agroecology' AND 'employment' and 'agroecology' AND 'income' provided only $8.2 \%$ of the overall search results for 'agroecology'.

\subsection{Findings}

As Section 3.1 shows, there is a positive trend between adopting certain agroecological practices for yield and farm profitability. The positive trend found for yield was confirmed by also using general linear mixedeffects models. Section 3.2 demonstrates that yields were $16 \%$ greater for agroecological practices compared to conventional practices. This is an aggregate result from a meta-analysis of 17 papers where yields were analysed. However, results for farm profitability show that despite the slight increase when adopting agroecological practices, this is not statistically significant. Even though the result for farm profitability is not significant by using linear mixed-effects models, the confidence interval for farm profitability covers more positive than negative values when adopting agroecological practices.

Our review points out that only limited data are available on the socio-economic effects of adopting agroecological practices at the farm level. Although many tools to assess sustainability already exist (e.g. CoBRA from UNDP and SAFA from FAO), a comprehensive, flexible and easily interpreted framework to capture simultaneously socio-economic indicators needs to be developed (Garibaldi et al., 2017).

The analysis up to this point has focused on the application of specific practices. We now explain the results obtained with respect to the economic indicators of yield, labour productivity, labour demand and farm profitability in light of the interaction with the overall agroecological systems in which specific practices are often applied. Many of the practices included in the quantitative analysis fit into the following agroecological systems: conservation agriculture $(C A)$, organic agriculture (OA), system of rice intensification (SRI), ecosystem approach to aquaculture (EAA). While the literature on these systems is vast, we narrow the discussion below to only those studies 
that address the four socio-economic indicators previously mentioned. Additionally, a few practices cut across more than one system and are covered under the category of cross-cutting practices.

\subsubsection{Conservation agriculture}

CA aims to achieve sustainable and profitable agriculture through the application of the three principles: minimal soil disturbance, permanent soil cover and crop rotations (Lal, 2015; Li, He, Bharucha, Lal, \& Pretty, 2016). These principles are not site-specific but represent fixed objectives that are applied to extend CA technologies efficiently across all production environments (Chauhan, Singh, \& Mahajan, 2012). Compared to conventional agriculture, it has been pointed out that CA maintains or increases crop yields, improves soil fertility and reduces soil erosion (Kassam, Friedrich, Shaxson, \& Pretty, 2009) under certain conditions (Pittelkow et al., 2014). Changing traditional tillage systems into conservational tillage, which may include no till, strip till, ridge till and mulch till, is an effective factor in decreasing diesel fuel energy consumption because of the resulting decrease in tillage operations, change in irrigation methods and reduction in human labour (Eskandari \& Attar, 2015). In fact, fewer trips across the field save time and money (lowering fuel, labour and machinery maintenance costs) and reduce soil compaction that can interfere with plant growth. Additionally, cover crops reduce the need for expensive chemical inputs.

Direct seeding, which is in many cases associated with zero tillage and mulching, makes CA considerably less labour intensive than conventional farming and more cost-effective. Dawe (2005) estimated that daily 5 person $\mathrm{ha}^{-1}$ were required for broadcasting compared with $25-50$ person $\mathrm{ha}^{-1}$ that is required for transplanting. Malabayabas, Kajisa, Mazid, Palis, and Johnson (2014) demonstrated that the combination of direct seeding applied to early maturing varieties of rice generates an increased farm income because of higher yields and reduced labour costs for crop establishment in the wet season.

Ineffective weed control is a major constraint to the adoption of CA (Broudera \& Macphersonba, 2014; Chauhan et al., 2012). Weed management issues in CA range from the control of the pre-plant fallow vegetation to the management of plant residues. Additionally, weed control management often requires extra labour in direct-seeded fields and it varies from field to field and season to season.
Economic parameters such as labour cost and farm gate price become extremely important in order to determine the profitability of direct seeding method. Taking into account these variables, Newby, Cramb, and Manivong (2011) estimated that direct seeding would be more profitable than transplanting even with yield reduction up to $600 \mathrm{~kg} \mathrm{ha}^{-1}$ for Laos rice farms.

The results presented by Gemtos, Galanopoulou, and Kavalaris (1998) indicate that by using minimal tillage, wheat can be established with lower energy consumption, less labour and less equipment than with conventional tillage. The wheat harvests recorded are equal to, or even higher than those achieved by conventional tillage (Gemtos et al., 1998).

\subsubsection{System of rice intensification}

$\mathrm{SRI}$ is an agroecological methodology for improving rice production by changing the management of plants, soil, water and nutrients (Peace Corps, 2015). On average, grain yields increased $24 \%$ under SRI compared to traditional flooded rice in China (Zhao, Wu, Dong, \& Li, 2010). Uphoff, Rafaralahy, and Rabenandrasana (2002) underlined that the main objective of SRI is to achieve higher factor productivity from land, labour, capital and water used in rice production in ways that benefit farmers, especially poorer ones.

Gautam, Sharma, Rana, Lal, and Joshi (2013) and Choudhary and Suri (2013) agree with the important role of optimal plant spacing practice in rice cultivation as it improves yield and profitability. Reducing the seed rate from $100 \mathrm{~kg} \mathrm{ha}^{-1}$ to $80 \mathrm{~kg} \mathrm{ha}^{-1}$ (Choudhary \& Suri, 2013) and from 25 hills $/ \mathrm{m}^{2}$ to 11 hills $/ \mathrm{m}^{2}$ (Gautam et al., 2013), growth and yield attributes increase. Better crop growth and productivity under reduced seed rate might be related to: (i) reduced plant competition for space, light, plant nutrients and water; (ii) increased tillering ability; (iii) enhanced photosynthesis efficiency; (iv) source-sink relationships (Barison \& Uphoff, 2011; Mishra \& Salokhe, 2011). This improvement in the seed rate was found to reduce the seed input use in rain-fed paddy, leading to enhanced resource use efficiency, paddy productivity and profitability (Choudhary \& Suri, 2013). Thus, decreased costs for seed inputs can result in several positive economic outcomes.

Considerable debate about SRI focuses on the increased demand for farm labour in SRI production (FAO, 2016). For example, a study conducted in the Gambia by Ceesay, Reid, Fernandes, and Uphoff (2006) identified labour costs for transplanting were 
more than twofold compared to conventional flooded rice costs. Technical innovations, such as seedling trays that simplify seedling preparation and transplanting, could reduce SRI labour needs (Ceesay et al., 2006).

\subsubsection{Organic agriculture}

OA farming systems are regulated under various laws and certification programmes. The basic rules of $\mathrm{OA}$ productions are that almost all synthetic inputs are prohibited and 'soil-building' crop rotations are mandated (FAO, 1999). Smith, Barbercheck, Mortensen, Hyde, and Hulting (2011) highlighted that most farmers transitioning from conventional agriculture to OA experienced yield losses. However, yields increased significantly once the agro-ecosystems are restored and organic management practices are fully implemented (Scialabba \& Hattam, 2002). Despite this, US farmers seem to be affected more by increased labour demand, due to weed management in the fields, than lower harvests (Scialabba \& Hattam, 2002). Smith et al. (2011) emphasized the need to find strategies for minimizing the costs associated with fertilization and management of weeds in organic cultivation, which are necessary to improve the profitability and sustainability of $O A$.

According to the study of Maruthi Sankar et al. (2014), the combination of farmyard manure, urea and phosphorus ${ }^{6}$ led to an increase in terms of yield and farm profitability, compared to the application of chemical fertilizers only. This result comes from a long-term experiment which has been conducted on cotton (Gossypium hirsutum) from 1987 to 2007 with eight different fertilizer treatments. ${ }^{7}$

Chaturvedi, Chandel, and Singh (2012) presented the results of an experiment conducted in India during rainy seasons applying two levels of fertilization: $50 \%$ and $100 \%$ recommended $\mathrm{NPK}^{8}$ in combination with organic manures ${ }^{9}$ and supplementary nutrients such as Boron. The application of organic manures and chemical fertilizer at the $50 \%$ level was essential for obtaining higher productivity $\left(32.5 \mathrm{q} \mathrm{ha}^{-1}\right)$ and profitability $\left(21,175 \mathrm{Rs} \mathrm{ha}^{-1}\right)^{10}$ of soybean as well as maintaining soil fertility compared to the application of only NPK at $100 \%$ level (31.29 $\mathrm{q} \mathrm{ha}^{-1}$ and 19,642 Rs ha ${ }^{-1}$ ) (Chaturvedi et al., 2012). In line with this, Demelash, Bayu, Tesfaye, Ziadat, and Sommer (2014) specified that by combining compost with inorganic fertilizers, farmers can reduce inorganic fertilizer dependency by $50 \%$. Reducing the costly application of chemicals makes the agroecological approach more profitable. The application of organic manures and compost is necessary for maintaining soil fertility in the long term. Demelash et al. (2014) highlighted that the residual effect from a year's application of compost $^{11}$ produced yield benefits ranging from $7 \%$ to $271 \%$. This indicates that farmers who cannot afford to apply compost every year could still improve productivity by applying compost every other year. From this perspective, using compost and organic matter, which also provides vital supplements and essential nutrients to the plants, represents a concrete response to declining land productivity, caused by chemical fertilizers degrading soil and the environment (Bejbaruaha, Sharma, \& Banik, 2013; Sharma \& Banik, 2014).

The studies we included in the meta-analysis did not consider organic price premiums. ${ }^{12}$ The research conducted by Crowdera and Reganold (2015) found that when actual premiums were considered in the cost-benefit analysis, OA is significantly more profitable (22-35\%) than conventional agriculture.

\subsubsection{Ecosystem approach to aquaculture}

The rationale for EAA is the recycling of waste products from one species to feed a second species (Chopin, 2006). Liu, Hu, Dai, and Avnimelech (2014) evaluated the effects on yield, water quality, formation of bioflocs and economic return in an integrated multi-aquaculture system comprising white shrimp, spotted scat and water spinach compared to a shrimp monoculture model. The integrated aquaculture system of shrimp, spotted scat and water spinach improved productivity, profitability and water quality.

Dela Cruz, Sevilleja, and Torres (2003) and Mohanty, Verma, and Brahmanand (2004) underlined that rice production can increased by $8-15 \%$ in the integrated aquaculture system compared with the conventional one. Wahab, Kunda, Azim, Dewan, and Thilsted (2008) described a concurrent rice-prawn-mola system where farmers can derive income from the selling of high-value prawns and ensure family nutrition by consuming rice and fish: the highest net benefit and profit margin were $75,002 \mathrm{BDT}^{13}$ and $72 \%$ respectively.

Buschmann, Troell, and Kautsky (2001) emphasized the importance of cultivation of filter feeders and seaweed around fish culture cages for waste recycling: particularly with the aim to integrate the cultivation of the agarophyte Gracilaria with salmon. The development of such practices would certainly be less expensive and labour intensive than implementing and 
respecting regulations on conventional waste treatment (Folke, Kautsky, \& Troell, 1994).

The study conducted by Thakur, Mohanty, Singh, and Patil (2015) assessed the synergies between various practices of integrated farming systems. This study demonstrated that integrating aquaculture and horticulture with SRI management can further improve yield and net water productivity and, therefore, provide smallholders an option of enhancing their income while improving their food security and livelihood.

These results suggest that EAA minimizes waste from culture systems, reduces the risk of disease and provides additional income for farmers.

\subsubsection{Cross-cutting practices}

Small-scale water-conserving irrigation practices have the potential to provide benefits at the farm level, increasing productivity, profitability and water use efficiency (Purcell, 1997). In the meta-analysis, two irrigation practices were considered: (i) integrated ridgefurrow with plastic mulching; and (ii) drip irrigation.

Integrated ridge-furrow and plastic mulching greatly improved tuber yield, output, net revenue and water use efficiency of potato compared to nonmulched treated control (Qin, Zhang, Dai, Wang, \& Li, 2014). Zhao et al. (2014) stressed that under scarce rainfall conditions during the early growth period, full mulching with plastic film was advantageous for enhancing potato yields and water use efficiency. Despite the higher cost $\left(10,819.8 \mathrm{Rmb} \mathrm{ha}^{-1}\right)^{14}$ in mulching material and labour compared to the group without mulching (7509.5 Rmb ha-1), the economic benefits were higher for full mulching group. Overall, the technique of full plastic film mulching on ridge-furrow is preferable for farmers living in semiarid rain-fed regions (Zhao et al., 2014).

The aim of the study conducted by Sandri, Pereira, and Vargas (2014) was to evaluate the production cost and profitability of watermelon during several years. In the experiment, drip and furrow irrigation were compared. The maximum yield was obtained adopting the furrow irrigation system with water depth equivalent to $125 \%$ of the crop evapotranspiration. However, water consumption in drip irrigation was $29 \%$ lower than that in furrow irrigation (Sandri et al., 2014). Numerous studies demonstrated that drip irrigation systems lead to more effective water use efficiency than conventional irrigation practices (e.g. furrow irrigation) (Gärdenäs, Hopmans, Hanson, \& Šimůnek, 2005).

\section{Conclusion}

This study collected quantitative evidence on the social and economic effects of agroecology from a selection of scientific publications. Based on the reviewed papers, evidence suggests that agroecological practices enhance financial capital, contributing to SL framework at the farm level.

Results for yield and farm profitability provided by vote counting and linear mixed-effects models followed similar patterns. It needs to be acknowledged that there is high variability and uncertainty among the results collected for farm profitability, while for other indicators (e.g. income stability), data have not been found. In this regard, we emphasize that:

- The available data are limited to peer-reviewed studies, most of which do not address the holistic agroecological approaches or reflect farm (rather than experiment station) conditions.

- Other co-variables (e.g. rainfall levels) need to be considered in any future development of the analysis in order to provide a more exhaustive explanation of the results.

- Additional attributes of agroecological approaches - for example practices that have cultural values or that build natural assets such as watershed services - contribute to the overall outcomes and should be considered in the totality of evaluation.

- There is a lack of evidence of interactive effects across practices; the combination of agroecological practices and their interactions deserve further analysis, in order to explore the potential of future agroecological systems.

- Qualitative methods (e.g. Q-methodology) should be integrated in order to capture farmer perspective.

\section{Notes}

1. Relevant Farm/Community-level indicators have been identified in this study.

2. http://www.scopus.com/ (accessed January and February 2015).

3. The practice use of compost or organic matter was searched as follow: 'use of compost' or 'organic matter'. Small-scale water-conserving irrigation was searched using the keyword 'water use efficiency'.

4. Articles appearing multiple times in the ranking were considered only once.

5. Based on a Scopus database analysis conducted on 21 May 2015. Cumulative results are from 1995-2015.

6. Composition: $25 \mathrm{~kg} \mathrm{~N}$ (farmyard manure) $+25 \mathrm{~kg} \mathrm{~N}$ (urea) $+25 \mathrm{~kg} \mathrm{P}$ (phosphorus) per hectare. 
7. The study compares the adoption of integrated nutrient management and biological $\mathrm{N}$ fixation with chemical fertilizers. We considered agroecological treatments those that have less chemical an increased quantity of compost or organic matter (e.g. farmyard manures) compared to those considered conventional.

8. Compositions: $50 \%$ recommended NPK corresponds to $10 \mathrm{~kg}(\mathrm{~N})+30 \mathrm{~kg}(\mathrm{P})+20 \mathrm{~kg}(\mathrm{~K})$ per hectare; $100 \%$ recommended NPK corresponds to $20 \mathrm{~kg}(\mathrm{~N})+60 \mathrm{~kg}(\mathrm{P})$ $240 \mathrm{~kg}(\mathrm{~K})$ per hectare.

9. Organic manures $\left(10 \mathrm{t} \mathrm{ha}^{-1}\right)$.

10. Currencies are given in Indian Rupees.

11. A compost prepared through heap method out of $40 \%$ cactus and crop residue, $10 \%$ vegetable and fruit peels (avocado, mango and vegetable skins), 20\% animal manure, $10 \%$ ash, $5 \%$ soil, and $15 \%$ cattle urine.

12. The price premiums reflect consumers' willingness to pay for attributes and additional production costs associated with organic foods, such as organic certification and the lack of pesticides during production.

13. Currencies are given in Bangladeshi Taka.

14. Currencies are given in Chinese Renminbi.

\section{Acknowledgements}

The authors thank two anonymous reviewers who provided excellent feedback to improve the quality of this manuscript. Moreover, many thanks to Prof. Mariacristina Piva and Prof. Emanuele $A$. Vendramini for their support.

\section{Disclosure statement}

No potential conflict of interest was reported by the authors.

\section{Funding}

This work was supported by the Doctoral School on the AgroFood System (Agrisystem) of the Università Cattolica del Sacro Cuore (Italy) and the Food and Agriculture Organization of United Nations (FAO). The views expressed in this publication are those of the authors and do not necessarily reflect the views of FAO.

\section{ORCID}

Raffaele D'Annolfo (D) http://orcid.org/0000-0002-3002-210X Barbara Gemmill-Herren (iD) http://orcid.org/0000-0003-4991640X

Benjamin Graeub (iD http://orcid.org/0000-0002-8070-9612

Lucas A. Garibaldi (iD http://orcid.org/0000-0003-0725-4049

\section{References}

Altieri, M. A. (2002). Agroecology: The science of natural resource management for poor farmers in marginal environments. Agriculture, Ecosystems and Environment, 93, 1-24.
Bacon, C. M., Getz, C., Kraus, S., Montenegro, M., \& Holland, K. (2012). The social dimensions of sustainability and change in diversified farming systems. Ecology and Society, 17, 41.

Barison, J., \& Uphoff, N. (2011). Rice yield and its relation to root growth and nutrient-use efficiency under SRI and conventional cultivation: An evaluation in Madagascar. Paddy and Water Environment, 9, 65-78.

Bates, D., Mäechler, M., Bolker, B., \& Walker, S. (2015). Fitting linear mixed-effects models using Ime4. Journal of Statistical Software, 67, 1-48.

Baumann, P. (2002). Improving access to natural resources for the rural poor. A critical analysis of central concepts and emerging trends from a sustainable livelihoods perspective. FAO, LSP WP 1, Access to Natural Resources Sub-Programme. Rome: FAO.

Bejbaruaha, R., Sharma, R. C., \& Banik, P. (2013). Split application of vermicompost to rice (Oryza sativa L.): Its effect on productivity, yield component and $\mathrm{N}$ dynamics. Organic Agriculture, 3, 123-128.

Borenstein, M., Hedges, L. V., Higgins, J. P. T., \& Rothstein, H. R. (2009). Introduction to meta-analysis. Chichester: John Wiley $\&$ Sons Ltd.

Broudera, S. M., \& Macphersonba, H. G. (2014). The impact of conservation agriculture on smallholder agricultural yields: A scoping review of the evidence. Agriculture, Ecosystems and Environment, 187, 11-32.

Buschmann, A., Troell, M., \& Kautsky, N. (2001). Integrated algal farming: A review. Cahiers de Biologie Marine, 42, 83-90.

Ceesay, M., Reid, W., Fernandes, E., \& Uphoff, N. (2006). The effects of repeated soil wetting and drying on lowland rice yield with System of Rice Intensification (SRI) methods. International Journal of Agricultural Sustainability, 4, 5-14.

Cepeda, M. A., \& Gómez, B. L. (2010). Respuesta de la canola (Brassica napus) a diferentes sistemas de labranza de conservación en secano en la Meseta Purhépecha, Michoacán, México. ITEA, 106, 282-293.

Chaturvedi, S., Chandel, A. S., \& Singh, A. P. (2012). Nutrient management for enhanced yield and quality of soybean (Glycine max.) and residual soil fertility. Legume Research, 35, 175-184.

Chauhan, B. S., Singh, R. G., \& Mahajan, G. (2012). Ecology and management of weeds under conservation agriculture: $A$ review. Crop Protection, 38, 57-65.

Chopin, T. (2006). Integrated multi-trophic aquaculture. What it is and why you should care and don't confuse it with polyculture. Northern Aquaculture, 12, 4.

Choudhary, A. K., \& Suri, V. K. (2013). On-farm participatory technology development effects on resource conservation technologies in rainfed upland paddy in Himachal Pradesh. Communications in Soil Science and Plant Analysis, 44, 26052617.

Cleary, B. D., Baumann, P., Bruno, M., Flores X., \& Warren, P. (2003). People-centred approaches. A brief literature review and comparison of types. FAO, LSP WP 5, People-Centered Approaches in Different Cultural Contexts Sub- Programme. Rome: FAO.

Corbier-Barthaux, C., Loyer, D., \& Richard, J. F. (2007). DMC at a glance: A quick DMC refresher for hurried readers. In Direct seeding mulch-based cropping systems (DMC) (pp. 11-12). Paris: AFD-FFEM.

Crowdera, D. W., \& Reganold, J. P. (2015). Financial competitiveness of organic agriculture on a global scale. Proceedings of the National Academy of Sciences, 112, 7611-7616. 
Dawe, D. (2005). Increasing water productivity in rice-based systems in Asia-past trends, current problems, and future prospects. Plant Production Science, 8, 221-230.

Dela Cruz, C. R., Sevilleja, R. C., \& Torres, J. (2003). Sistema arrozpeces en Nuvea Ecija, Filipinas. In Agro-acuicultura integrada: manual básico (pp. 90-94). FAO Documento Técnico de Pesca N. 407. Rome: FAO.

Demelash, N., Bayu, W., Tesfaye, S., Ziadat, F., \& Sommer, R. (2014). Current and residual effects of compost and inorganic fertilizer on wheat and soil chemical properties. Nutrient Cycling in Agroecosystems, 100, 357-367.

DFID. (1999). Sustainable Livelihoods Guidance Sheets. Retrieved from http://www.eldis.org/vfile/upload/1/document/0901/ section2.pdf

Dumont, A. M., Vanloqueren, G., Stassart, P. M., \& Baret, P. V. (2016). Clarifying the socioeconomic dimensions of agroecology: Between principles and practices. Agroecology and Sustainable Food Systems, 40, 24-47.

Eskandari, H., \& Attar, S. (2015). Energy comparison of two rice cultivation systems. Renewable and Sustainable Energy Reviews, 42, 666-671.

FAO. (1999). Committee on agriculture: Fifteenth session. Organic agriculture. Retrieved from http://www.fao.org/ docrep/meeting/X0075e.htm\#P96_7257

FAO. (2014). The 3 principles of conservation agriculture. Retrieved from http://www.fao.org/assets/infographics/CAprinciples-Infographic.pdf

FAO. (2015). Agroecology for food security and nutrition. Proceedings of the FAO International Symposium, 18-19 September 2014. Rome, Italy: FAO.

FAO. (2016). Farming systems that save and grow, In Save and grow, in practice: Maize, rice, wheat. A guide to sustainable cereal production (pp. 37-82). Rome: FAO.

Folke, C., Kautsky, N., \& Troell, M. (1994). The cost of eutrophication from salmon farming: Implications for policy. Journal of Environmental Management, 40, 173-182.

Francis, C., Lieblein, G., Gliessman, S., Breland, T. A., Creamer, N., Harwood, R.,... Poincelot, R. (2003). Agroecology: The ecology of food systems. Journal of Sustainable Agriculture, 22, 99-118.

Fukai, S., \& Ouk, M. (2012). Increased productivity of rainfed lowland rice cropping systems of the Mekong region. Crop and Pasture Science, 63, 944-973.

Garbach, K., Milder, J. C., DeClerck, F. A. J., Montenegro, M., Driscoll, L., \& Gemmill-Herren, B. (2016). Examining multi-functionality for crop yield and ecosystem services in five systems of agroecological intensification. International Journal of Agricultural Sustainability, published online first 28 April 2016. doi:10.1080/14735903.2016.1174810

Garbach, K., Vu Thanh, T. A., Buchori, D., Ravanera, R., Boualaphanh, C., Ketelaar, J. W., \& Gemmill-Herren, B. (2014). The multiple goods and services of Asian rice production systems. Rome: FAO.

Gärdenäs, A., Hopmans, J., Hanson, B., \& Šimůnek, J. (2005). Twodimensional modelling of nitrate leaching for various fertigation scenarios under micro-irrigation. Agricultural Water Management, 74, 219-242.

Garibaldi, L. A., Dondo, M. B., Hipolito, J., Azzu, N., Viana, B. F., \& Kasina, M. (2016). A quantitative approach to the socio-economic valuation of pollinator-friendly practices: $A$ protocol for its use. FAO, Pollination Services for Sustainable Agriculture. Rome: FAO.

Garibaldi, L. A., Gemmill-Herren, B., D'Annolfo, R., Graeub, B., Saul, A. C., \& Breeze, T. D. (2017). Farming approaches for greater biodiversity, Livelihoods, and food security. Trends in Ecology \& Evolution, 32, 68-80.

Gautam, P., Sharma, G. D., Rana, R., Lal, B., \& Joshi, E. (2013). Evaluation of integrated nutrient management and plant density on productivity and profitability of rice (Oryza sativa) under system of rice intensification in mid-hills of Himachal Pradesh. Indian Journal of Agronomy, 58, 421-423.

Gelman, A., \& Hill, J. (2007). Data analysis using regression and multilevel/hierarchical models. Cambridge, UK: Cambridge University Press.

Gemtos, T. A., Galanopoulou, S., \& Kavalaris, C. (1998). Wheat establishment after cotton with minimal tillage. European Journal of Agronomy, 8, 137-147.

Gliessman, S. R. (2007). Agroecology: The ecology of sustainable food systems. Boca Raton: CRC Press, Taylor \& Francis Group.

IAASTD. (2009). Agriculture at a crossroads. Washington, DC: Island Press.

IFAD. (2011). Rural Poverty Report 2011. Retrieved from https:// www.ifad.org/documents/10180/c47f2607-3fb9-4736-8e6aa7ccf3dc7c5b

Kassam, A., Friedrich, T., Shaxson, F., \& Pretty, J. (2009). The spread of conservation agriculture: Justification, sustainability and uptake. International Journal of Agriculture Sustainability, 7, 292-320.

Knowler, D., \& Bradshaw, B. (2007). Farmers' adoption of conservation agriculture: A review and synthesis of recent research. Food Policy, 32, 25-48.

Lal, R. (2015). A system approach to conservation agriculture. Journal of Soil and Water Conservation, 70, 82A-88A.

Lestrelin, G., Quoc, H. T., Jullien, F., Rattanatray, B., Khamxaykhay, C., \& Tivet, F. (2012). Conservation agriculture in Laos: Diffusion and determinants for adoption of direct seeding mulch-based cropping systems in smallholder agriculture. Renewable Agriculture and Food Systems, 27, 81-92.

Li, H., He, J., Bharucha, Z. P., Lal, R., \& Pretty, J. (2016). Improving China's food and environmental security with conservation agriculture. International Journal of Agricultural Sustainability, 14, 377-391.

Liu, L., Hu, Z., Dai, X., \& Avnimelech, Y. (2014). Effects of addition of maize starch on the yield, water quality and formation of bioflocs in an integrated shrimp culture system. Aquaculture, 418-419, 79-86.

Malabayabas, A. J. B., Kajisa, K., Mazid, M. A., Palis, F. G., \& Johnson, D. E. (2014). Impacts of direct-seeded and early-maturing varieties of rice on mitigating seasonal hunger for farming communities in northwest Bangladesh. International Journal of Agricultural Sustainability, 12, 459-470.

Marshall Bradley, F., Ellis, B. W., \& Phillips, E. (2009). Rodale's ultimate encyclopedia of organic gardening: The indispensable green resource for every gardener (3rd edition). Rodale Books.

Maruthi Sankar, G. R., Sharma, K. L., Gabhane, V. V., Nagdeve, M. B., PushpanjaliOsman, M., Pushpanjali, G., ... Sammi Reddy, M. (2014). Effects of long-term fertilizer application and rainfall distribution on cotton productivity, profitability, and soil fertility in a semi-arid vertisol. Communications in Soil Science and Plant Analysis, 45, 362-380. 
MEA. (2005). Ecosystems and human well-being. Washington, DC: Island Press.

Mishra, A., \& Salokhe, V. M. (2011). Rice root growth and physiological responses to SRI water management and implications for crop productivity. Paddy and Water Environment, 9, 41-52.

Mohanty, R. K., Verma, H. N., \& Brahmanand, P. S. (2004). Performance evaluation of rice-fish integration system in rainfed medium land ecosystem. Aquaculture, 230, 125-135.

Newby J., Cramb R. and Manivong, V. (2011). Economic analysis of productivity interventions in rainfed low land rice systems. 28th International Rice Research Conference. Hanoi, Vietnam.

Peace Corps. (2015). System of Rice Intensification (SRI). Volunteer Handbook (M0118V). Retrieved from http://pclive. peacecorps.gov/pclive/index.php/agriculture/item/565system-of-rice-intensification-sri-volunteer-handbookm0118v

Pittelkow, C. M., Liang, X., Linquist, B. A., van Groenigen, K. J., Lee, J., Lundy, M. E., ... van Kessel, C. (2014). Productivity limits and potentials of the principles of conservation agriculture. Nature, 517, 365-368.

Pretty, J. (2008). Agricultural sustainability: Concepts, principles and evidence. Philosophical Transactions of the Royal Society B: Biological Sciences, 363, 447-465.

Prokopy, L. S., Floress, K., Klotthor-Weinkauf, D., \& Baumgart-Getz, A. (2008). Determinants of agricultural best management practice adoption: Evidence from the literature. Journal of Soil and Water Conservation, 63, 300-311.

Purcell, R. (1997). Potential for small-scale irrigation in SubSaharan Africa: The Kenyan example. Retrieved from http:// www.fao.org/docrep/w7314e/w7314e07.htm

Qian, S. S., Cuffney, T. F., Alameddine, I., Mc Mahon, G., \& Reckhow, K. H. (2010). On the application of multilevel modeling in environmental and ecological studies. Ecology, 91, 355361.

Qin, S., Zhang, J., Dai, H., Wang, D., \& Li, D. (2014). Effect of ridgefurrow and plastic-mulching planting patterns on yield formation and water movement of potato in a semi-arid area. Agricultural Water Management, 131, 87-94.

Rathore, V. S., Singh, J. P., Meel, B., \& Nathawat, N. S. (2014). Agronomic and economic performances of different cropping systems in a hot, arid environment: A case study from Northwestern Rajasthan, India. Journal of Arid Environments, 105, 75-90.

R Development Core Team. (2013). R: A language and environment for statistical computing. R Foundation for Statistical Computing, Vienna, Austria.

Rusinamhodzi, L., Corbeels, M., Van Wijk, M. T., Rufino, M. C., Nyamangara, J., \& Giller, K. E. (2011). A meta-analysis of long-term effects of conservation agriculture on maize grain yield under rain-fed conditions. Agronomy for Sustainable Development, 31, 657-673.

Sandri, D., Pereira, J. A., \& Vargas, R. B. (2014). Production costs and profitability of watermelon under different water depths and irrigation systems. Irriga, Botucatu, 19, 414-429.

Scialabba, N. and Hattam, C. (2002). Organic agriculture, environment and food security. FAO, Environment and Natural Resources Series N. 4. Rome: FAO.

Sharma, R. C., \& Banik, P. (2014). Vermicompost and fertilizer application: Effect on productivity and profitability of baby corn (Zea mays I.) and soil health. Compost Science \& Utilization, 22, 83-92.

Smith, R. G., Barbercheck, M. E., Mortensen, D. A., Hyde, J., \& Hulting, A. G. (2011). Yield and net returns during the transition to organic feed grain production. Agronomy Journal, 103, 51-59.

Soussana, J. F., Tichit, T., Lecomte, P., \& Dumont, B. (2015). Agroecology: Integration with livestock, In Agroecology for Food Security and Nutrition: Proceedings of the FAO International Symposium (pp. 225-249). 18-19 September 2014. Rome, Italy: FAO.

Thakur, A. K., Mohanty, R. K., Singh, R., \& Patil, D. U. (2015). Enhancing water and cropping productivity through Integrated System of Rice Intensification (ISRI) with aquaculture and horticulture under rainfed conditions. Agricultural Water Management, 161, 65-76.

Tittonell, P. (2015). Food security and ecosystem services in a changing world: It is time for agroecology. In Agroecology for Food Security and Nutrition: Proceedings of the FAO International Symposium (pp. 16-31), 18-19 September 2014. Rome, Italy: FAO.

Tittonell, P., Scopel, E., Andrieu, N., Posthumus, H., Mapfumo, P., Corbeels, M.,... Mkomwa, S. (2012). Agroecology-based aggradation-conservation agriculture (ABACO): Targeting innovations to combat soil degradation and food insecurity in semi-arid Africa. Field Crops Research, 132, 168-174.

Tucker, J. and Yirgu, L. (2010). Small-scale irrigation in the Ethiopian highlands. What potential for poverty reduction and climate adaptation? RiPPLE Briefing Paper N. 3 August 2010. Addis Ababa: RiPPLE.

Uphoff, N. (2008). The system of rice intensification (SRI) as a system of agricultural innovation. Jurnal Tanah dan Lingkungan, 10, 27-40.

Uphoff, N., Rafaralahy, S., \& Rabenandrasana, J. (2002). What is the system of rice intensification? In Assessments of the system of rice intensification (SRI): Proceedings of an international conference held in Sanya, China, April 1-4, 2002. Ithaca, USA, CIIFAD, 5-7.

Wagner, S. C. (2011). Biological nitrogen fixation. Nature Education Knowledge, 3, 15.

Wahab, M., Kunda, M., Azim, M. E., Dewan, S., \& Thilsted, S. H. (2008). Evaluation of freshwater prawn-small fish culture concurrently with rice in Bangladesh. Aquaculture Research, 39, 1524-1532.

Wezel, A., Casagrande, M., Celette, F., Vian, J. F., Ferrer, A., \& Peigné, J. (2014). Agroecological practices for sustainable agriculture. A review. Agronomy for Sustainable Development, 34, $1-20$.

Wezel, A., \& Soldat, V. (2009). A quantitative and qualitative historical analysis of the scientific discipline of agroecology. International Journal of Agricultural Sustainability, 7, 3-18.

Zhao, H., Wang, R. Y., Ma, B. L., Xiong, Y. C., Qiang, S. C., Wang, C. L., ... Li, F. M. (2014). Ridge-furrow with full plastic film mulching improves water use efficiency and tuber yields of potato in a semi arid rainfed ecosystem. Field Crops Research, 161, 137-148.

Zhao, L., Wu, L., Dong, C., \& Li, Y. (2010). Rice yield, nitrogen utilization and ammonia volatilization as influenced by modified rice cultivation at varying nitrogen rates. Agricultural Sciences, 1, 10-16. 